\title{
Gerakan Lingkungan Komuntias Akademi Sampah Dalam Pembangunan Kepedulian Masyarakat Terhadap Sampah di Kota Cilegon
}

\section{Dedi Rustandi}

Ilmu Pemerintahan, FISIP Universitas Sultan Aeng Tirtayasa rustandidedi020@gmail.com

\section{Rian Bawazir}

Ilmu Pemerintahan, FISIP Universitas Sultan Aeng Tirtayasa riyanbawazir@gmail.com
E-ISSN (2721-0642)

Recieved:

June 102020

Revised:

August 132020

Accepted:

August 192020

Doi Number

10.37950/ijd.v2i2.55

\section{Abstract}

Along with environmental problems that are increasingly complex at this time, encouraging individuals and groups to protect their environment. The environmental movement is carried out by the Cilegon city academy community as an effort to care for the environment. This paper seeks to explain how the environmental movement in building public awareness of waste and the environment which is increasingly threatening the pollution of environmental balance. By using a qualitative analysis approach based on the activities carried out by the Garbage Academy community. There are two activities / movements carried out by the garbage academy. The first movement was through the environmental education movement which was carried out in the city of Cilegon by providing direct education to the Cilegon community. The second movement was a tree planting action carried out at SDN 1 Ciwedus in the city of Cilegon.

Keywords: waste academy community, environmental movement, building community awareness

\section{Abstrak}

Seiring dengan permasalahan lingkungan yang semakin kompleks pada saat ini, mendorong individu maupun kelompok harus menjaga lingkungannya. Gerakan lingkungan dilakukan 
oleh komunitas akademi kota cilegon sebagai upaya kepedulian terhadap lingkungan. tulisan ini berusaha menerangkan bagaimana gerakan lingkunagan dalam membangun kepedulian masyarakat terhadap sampah dan lingkungan yang semakin hari mengancam pencemaran keseimbangan lingkungan. Dengan menggunakan pendekatan analisis kualitatif berdasarkan kegiatan yang dilakukan oleh komunitas Akademi Sampah. Kegiatan/gerakan yang dilakukan akademi sampah terdapat dua gerakan. Gerakan pertama melalui gerakan edukasi lingkungan yang dilakukan di kota cilegon dengan membuat penyuluhan kepada masyarakat cilegon secara langsung. Gerakan yang kedua merupakan aksi menanam pohon yang dilakukan di SDN 1 Ciwedus yang berada di kota Cilegon.

Kata Kunci: komunitas akademi sampah, gerakan lingkugan, membangun kepedulian masyarakat

\section{Pendahuluan}

Permasalah lingkungan saat ini terjadi sangat kompleks sekali. Terdapat banyak hal membuat lingkungan semakin hari semakin buruk seperti timbulnya pemanasan global yang disebabkan oleh rumah kaca, pencemaran air sungai yang disebabkan oleh pembuangan limbah perusahaan tidak bertanggung jawab, longsor dan banjir bandang disebabkan oleh pembalakan liar dihulu sungai, sampai dengan banjir dan penurunan kuliatas tanah disebabkan oleh sampah. Sesuatu yang tidak memiliki nilai dimata penggunanya dan merupakan sebuah hasi produksi ialah sampah ( Risky dkk 2015). Sampah inilah terkadang hal sepale tapi memiliki dampak yang sangat signifikan.

Permasalahan sampah inilah yang saat ini harus menjadi memiliki perhatian lebih. Karena Keberadaannya yang tidak bisa dipisahkan dengan manusia yang hidup. Seperti yang kita ketahui bahwa setiap manusia pasti menghasilkan sampah. Baik itu sampah organic maupun non organic. Peningkatan keberadaan sampah saat ini sebanding dengan dengan semakin bertambahnya populasi manusia saat ini.

Di Indonesia sendiri permasalahahan sampah seakan-akan menjadi permasalahan yang tidak pernah ada habisnya. Karena kita ketahui sebagai Negara yang jumlah penduduk nya keempat terbesar dunia. Dengan begitu semakin tinggi jumlah penduduk suatu Negara makan semakain tinggi juga jumlah sampah yang ada semakin meningkat pula. Hal tersebut mendukung adanya pola konsumsi masyarakat yang tidak sedikit pula. Sehingga dari situlah muncul sampah yang tidak kita bisa pungkiri bahwa pasti setiap manusia akan menghasilkan sampah. Diperburuk dengan paradigma pengelolaan sampah di Indonesia yaitu dikumpulkan-diangkut-dan dibuang. Yang kita sadari bahwa cara tersebut sampai saat ini tidak menyelesaikan persoalan sampah.

Mengacu pada data yang dikeluarkan oleh Kementrian lingungan hidup ( KLH) bahwa setiap harinya masyarakat Indonesia menghasilkan sampah sebesar 0.8 kilogram per orang atau bila dihitung perhari sekitar 189 to per hari. Apabila tidak adanya pengolahan ataupun penaganagn maka jumlah tersebut akan terus bertambah setiap harinya. Angka tersebut sangat memprihatinkan untuk masa depan lingkungan Indonesia kedepannya. ( Didin, dkk 2019) 
Setiap aktifitas manusia yang dilakukan secara kelompok maupun pribadi, dirumah, dijalan, disekolah, dikampus, dikantor, dipasar mapun dimana saja akan menghasilkan sampah. Hal ini akan menjadi sebuah persoalan ketika kesadaran masyarakat sangat kurang. Seperti masih banyak yang buang sampah sembarangan, terlalu banyak menggunakan bahan-bahan yang menghasilkan sampah plastic dan lain sebagainya.

Secara umum kehidupan perkotaan besar juga sangat berkaitan erat dengan jumlah sampah yang dihasilkan (Mulyaningsih dkk, 2015). Dengan begitu setiap kota pasti akan mempunyai permasalah yang relative sama mengenai sampah. Karena pola konsumtif masyarakat kota lebih tinggi dibandingkan dengan masyarakat kampung. Sehingga sampah menjadi ancaman bagi masyarakat kota yitu Salah satunya adalah kota cilegon. Kota yang berada di provinsi banten ini bagian dari salah satu satu termasuk kota industry. Dengan jumlah penduduk yang cukup banyak dengan begitu akan menghasilkan sampah banyak juga.

Pemerintahan Indonesia sendiri telah mengeluarkan membuat peraturan mengenai pengelolaan sampah dengang adanya undang-undang RI. No 18 tahun 2008. Pasal 1, 20 dan 22. Yang mejelesakan pengelolaan sampah merupakan sebuah kegiatan yang tersistematis, menyeluruh, dan berkesinambungan meliputi pengurangan sampah yang antara lain : pembatasan timbulan sampah, pendauran ulang, pemanfaatan kembali sampah. Dengan penanganan sampah : pemilahan, pengumpulan, pengangkutan, pengolahan dan pemrosesan. ( Risky dkk 2015)

Sebenaranya keberadaan undang-undang itudengan begitu setiap pemerintah daerah diberikan kewenangan dalam pengelolaan sampah dengan menggunakan wawasan lingkungan dengan cara mengeluarkan kebijakan dan strategi pengelolaan sampah (Asteria \& Heruman, 2016). Terkadang undang-undang dibuat hanya sebagai tekstual saja, sedangkan realitasnya tidak ada. Sebuah pertanyaan yang ada dibenak saya apakah sudah ada kebjakan pemerintah yang menyelesaikan permasalahan tersebut dan jika sudah ada apakah sudah memberikan dampak. Tetapi sepertinya realitas dilapangan sampah masih menjadi permasalahan yang belum bisa terselesaikan. Maka dari itu perlu ada respon gerakan dari masyarakat terhadap persoalan tersebut.

Permasalah yang sangat serius ini harus didukung dengan adanya kesadaran masyarakat untuk menyelesaikan masalah tersebut (Anih Sri Suryani, 2014). Salah satunya adalah yang dilakukakan oleh salah satu komunitas yaitu akademi sampah yang berada di Kota Cilegon-Banten.

Akademi yang terbentuk pada 11 oktober 2019 didirikan oleh seorang aktifis lingkungan yaitu sodaara firdaus ini bergerak dalam menyelesaikan persoalan sampah dengan membangun kesadaran masyarakat mengenai pentingnya kesadaran terhadap sampah. Berdirinya komunitas ini berawal dari kekhawatiran firdaus dengan semakin banyaknya jumlah sampah yang beredar dilingkungan wilayah cilegon. Yang tidak dibarengi dengan kepedulian warga sekitar terhadap lingkungan.

Berdasrkan informasi yang didaptkan dengan pendirinya bahwa komunitas akademi sampah ini memiliki tujuan yang sejalan dengan landasan undang-undang dasar 45 tepatnya alinea ke 4 yaitu untuk mencerdaskan kehidupan bangsa. Hal tersebut didukung dengan beberapa program yang cukup menarik pertama, yang telah diakukan yaitu melakukan kegitan kursus bahasa inggris tetapi pesertanya 
harus membayar kursus tersebut dengan menggunakan sampah. Kedua, melakukan penyuluhan kepada masyarakat tentang peduli sampah dan peduli lingkungan dengan dibarengi pemanfaatan sampah menjadi kerajinan. Program selanutnya juga Dalam perjalannya yang baru sudah ada sedikit nya penanaman 50 pohon di SD 1 ciwedus. Dan kedepannya komunitas akademi sampah ini akan melakukan berbagai kegiatan dalam memberikan lebih bayak edukusai pada masyarakat.

Oleh karena itu berdasarkan persoalan yang telah dipaparkan secara menyeluruh diatas maka focus dalam penulisan jurnal ini adalah Bagaimana Gerakan Lingkungan Komunitas Akademi Sampah Dalam Membangun Kesadaran Masyarakat Sekitar Terhadap Lingkungan Melalui Pengelolaan Sampah.

\section{Kerangka Teori}

Gerakan kepedulian terhadap lingkungan sendiri merupakan salah satu termasuk gerakan social baru. Karena gerakan ini menyadari bahwa semakin memprihatinkanya kondisi lingkungan yang ada disekitarnya sehingga memunculkan kesadaran orang-orang yang berada disekitar lingkungan tersebut tentang pentingnya menjaga lingkungan.

Gerakan lingkungan sendiri menurut Jenkins, (1983) diartikan sebagai triguluasi gerakan politik dan social yang memiliki tujuan untuk melestaraikan dan memperbaiki lingkungan berbagai cara seperti melalui pendidikan kemasyarakatan, perbaikan dalam perencanaan komunitas, dan peningkatan regulasi pemerintah.

Aditjondro, (2003) mejelaskan bahwa terdapat tiga jenis gerakan lingkungan: "Pertama, Public environmentalist yang dimana usaha yang dilakukan oleh masyarakat berupa tindakan ataupun sikap meraka dalam upaya memperbaiki lingkungan yang berada disekitarnya. Kedua, Organized environmentalist yaitu memperbaiku lingkungan hidup dengan cara membuat organisasi-organisasi khusus, terkadang bisa menembus berbagai negar contoh nya GoGreen. Terakhir, Institusional environmental movement organization jenis ini individu atau kelompok bergerak menggunakan fasilitas lembaga-lembaga formal yang menganggap diri punya hak terhadap permasalahan lingkungan". Dari ketiga bentuk tresebut maka akan dilihat bagaiamana gerakan akademi sampah dalam bergerak melalui jalur mana.

Bentuk dari gerakan lingkungan dijelaskan oleh Schusler \& Krasny, memiliki lima bentuk antara lain (Nugroho, 2017):

1. physical environmental improvement atau perbaikan lingkungan fisik, focus dari bentuk ini berupaya pemulihan lingkungan fisik seperti sungai, taman kota dan yang lainnya (Suharko, 2014).

2. environmental education atau pendidikan lingkungan, bentuk aksinya biasanya berupa kegiatan dengan pendidikan seperti brosur, famplet video sebagai dai produksi media selain itu juga berupa pameran dan festival dan yang terpenting adlah pesan yang disampaikannya mengandung pendidikan. Dalam hal ini pendidikan dibagi menjadi dua dilakukan pendidikan secara langsung dan tidak langsung. Aksi pendidikan secara langsung dapat terlihta dari kontribusi yang dilakukan secara langsung dalam mengatasi permasalah lingkungan, menjaga lingkungan, pemanfaatan taman kota dan yang lainnya. Sedangkan pendidikan secara tidak langsung dapat terlihat dari tindakan bagaimana organisasi tersebut mempengaruhi orang lain agar mampu berkontribusi dalam penyelesaian 
masalah lingkungan dan menjaga lingkungan. Dalam hal ini pendidikan tidak langsung dapat berupa kampanye dan pembelajaran mengenai isu lingkungan.

Berkaitan dengan pendidikan lingkungan (Suharko , 2014) Menjelaskan bahwa para individu meningkatkan suatu pemikiran yang sangat mendalam tentang topic-topik lingkungan dan memiliki kemampuan untuk membuat keputusan yang mencukupi dan bisa dipertanggungjawabkan

3. inquiry atau Penelitian, aksinya dapat berupa mengevaluasi suatu tindakan, dan kegiatan berbasis riset ilmiah lainnya. Dalam penelitian (Nugroho, 2015) Salah satunya adalah konsep EcoResponsibility, dengan melakukan penelitian mengenai pengaruh dari adanya emisi gas buang kendaraan bermotor.

4. Analisis isu kebijakan public, Aksi ini berkaitan dengan dampak lingkungan yang terjadi sebagai konsekuensi dari pilihan dan implementasi kebijakan publik tertentu oleh pemerintah. Tindakannya ini bisa berupa menganalisis dampak lingkungan dari aturan yang dibuat tentang pembuangan limbah atau sampah cair ke suatu tempat tertentu yang bisa berupa sungai, laut ataupun yang lainnya dan memberikan rekomendasi kebijakan kepada komite legislative (Nugroho, 2015)..

5. community development, pemanfaatan sumberdaya local dalam aksi yang dilakukannya bisa berupa pengembangan produk makanna dan yang lainnya. Salah satu contohnya dalan aksi ini dilakukan oleh Gama Earth UGM dalam pembuatan dan pengembangan biogas sampah buah di Pasar Buah Gemah Ripah, Sleman (Nugroho, 2015).

\section{Metode Penelitian}

Penelitian ini menggunakan pendekatan deskriftif kualitatif. Menurut Sarosa (2012), penelitian kualitatif merupakan penelitian yang mencoba mengamati sebuah fenomena dengan konteks yang sebenarnya, sehingga peneliti tidak perlu memanipulasi phenomena yang diamatinya (Creswell, 2009). Jadi ketika menggunakan penelitian deskriftif kualitatif maka peneliti harus mampu menggambarkan kondisi atau situasi keadaan yang sebenarnya agar bisa menjadi kajiaan penelitian dalam tujuan penelitian.

Penelitian yang dilakukan melihat dan menganalisa bagaimana gerakan lingkungan yang dilakukan komunitas akademi sampah di kota Cilegon dengan menggunakan teori gerakan lingkungan menurut Schusler \& Krasny. Data yang dihasilkan melalui wawancara langsung dengan anggota, pengurus dari komuniitas akademi sampah dan masyarakat sekitar yang ikut berpartisipasi dalam kegiatan akademi sampah. Dengan berfokus pada sejarah pembentukan komunitas, kegiatankegiatan komunitas dan pengaruh gerakan komunitas terhadap kepedulian masyarakat terhadap sampah. Selain itu data didukung dengan hasil observasi langsung peneliti dengan menggikuti berbagai kegiatan yang dilakukan komunitas akademi sampah.

\section{Hasil dan Diskusi}

\section{Gerakan Lingkungan Akademi Sampah}

Dalam kebergerakan sesorang terhadap kepedulian lingkungan menurut Aditjondro, (2003) terdapat beberapa cara salah satunya adalah Organized 
environmentalist yaitu aksinya dalam memperbaiki lingkungan hidup menggunakan sarana organisasi-organisasi khusus yang telah didirikan. Inilah yang dilakukan oleh aktivis-aktivis peduli lingkungan yang ada di cilegeon (Hikmawan, Ika Indriyany, \& Ma'asan Mayrudin, 2019). Mereka membuat komunitas sebagai wadah dalam bergerak dalam menghidupkan kepedulian seseorang terhadap lingkungan. Mulai dari situlah muncul sebuah komunitas pada pada 11 oktober 2019 didirikan oleh seorang aktifis lingkungan yaitu sodaara firdaus ini bergerak dalam menyelesaikan persoalan sampah dengan membangun kesadaran masyarakat mengenai pentingnya kesadaran terhadap sampah. Saran-sarana organisasi ini menjadi jalan bagi bagaimana seseorang lebih pedui terhadapa sampah dan lingkungan. Komunitas di didukung oleh banyak golongna masyarakat yang peduli terhadapa lingkungan, mulai dari yotuber, anak muda, tokoh masyarakat dan golongan lainnya. Keberadaan akademi sampah ini di umur yang baru awal mendapat dukungan yang cukup positif dari masyarakat.

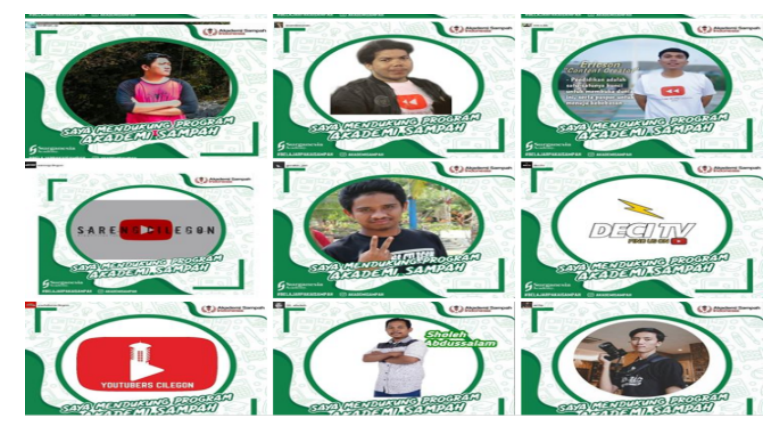

Dengan membuat program-program gerakan lingkungan yang cukup menarik dan dikemas dengan kekinian agar semua golongan masyarakat bisa berpartisipasi dalm setiap kegiatan-kegiatan dari akdemi sampah. Kegiatankegiatannya berfokus pada dua hal yang yang sangat penting. Yaitu kegiatan pendidikan membangun kepedulian terhadap lingkungan dan perbaikan lingkungan fisik.

\section{Edukasi lingkungan dan pengelolaan sampah}

Mengacu pada pendapat Nugroho (2017), “terdapat beberapa komponenutama dalam pendidikan lingkungan anatar laian: adanya kepekaan dan kesadaran mengenai tantang yang ada pada lingkungan, adnya pemahaman dan pengetahuan terhadap tantangan yang ada pada lingkungan, memiliki kepedualian dan ,otivasi yang tinggi untuk memperbaiki kulitas lingkungan, mempunyai keahlian dalam bidang analisa sebagai upaya menghadapi tantangan lingkungan, terakhir memiliki jiwa partisipasi yang tinggi dalam upaya memperbaiki lingkunga". Secara umum sendiri pendidikan dibedakan menjadi dua yaitu pendidikan non formal dan pendidikan formal yang dilakukan diluar pembelajaran sekolah. Yang dimana penegetahuan diberikan oleh teman, keluarga dan orang-orang yang ada disekitarnya. Dengan begitu melihat hal tersebut pendidikan yang dilakukan oleh akademi sampah termasuk dalam pendidikan non formal walaupun dalam pelaksanaannya mirif dengan sekolah.

Kegiatan edukasi menyasar sekolah dasar negeri 1 ciwedus cilegon banten. Agar siswa tidak merasa terbebani maka pendidikan ini dilakukan dengan sefleksibel mungkin. Dimana para anggota ataupun relawan akademi sampah 
memberikan motivasi dan materi bagaiamana mengelola sampah dengan bijak kemudian juga bagaimana melestraikan lingkungan jika kita kaitaitkan dengan teori Schusler \& Krasny dimana bentuk gerakan lingkungan adalah salah satunya environmental education atau pendidikan lingkungan,dimana bentuk aksinya biasanya berupa kegiatan yang mempunyai pesan pendidikan tetapi dikemas secara menarik seperti dengan menggunkakan media dengan membuat flayer, brosur, pameran dan bahkan festival. Salah atu kegiatan yang dilakukan oleh akademi smapah adalah dengan melakukan sosialisasi sampah untuk kebaikan pada tanggal 15 maret kemaren. Dengan melibatkan beberbagi kegiatan seperti fentas music, stand up comedy dan kegiatan lainnya. Sosilisasi ini juga bertujuan untuk memberi pemahaman kepada masyarakat terhadap pentingnya peduli lingkungan dan bagaimana mengelola sampah dengan baik. selian itu dalam kegiatan ini akademi sampah membuka donasi pohon, yang dimana pohon ini akan ditanam ditempattemapt yang telah ditargetkan oleh komunitas ini.

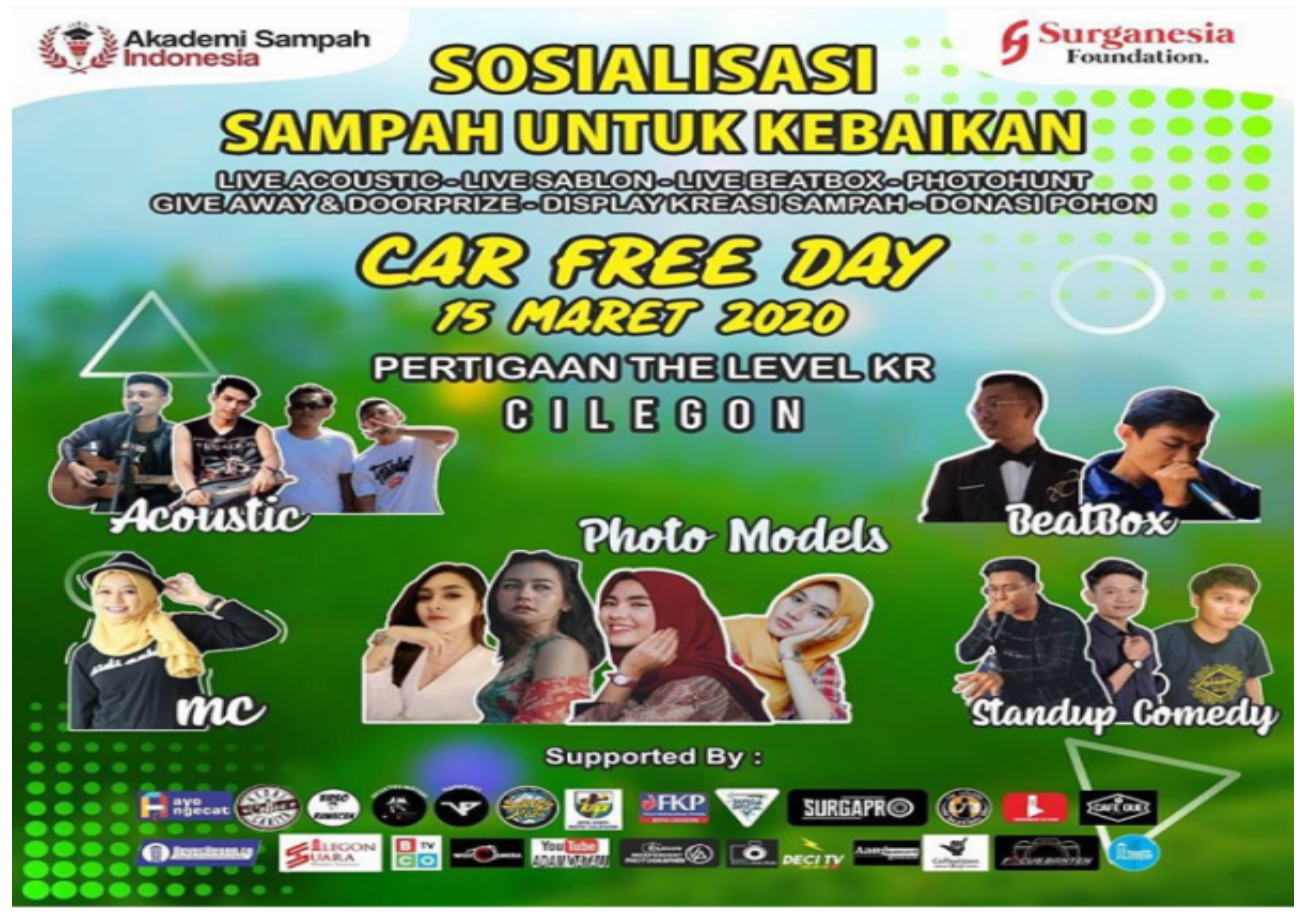

Kemudian selain melakukan kegiatan sosialisasi dalm pemebrian pendidikan para anggota yang tergabung dalam akademi sampah Indonesia ini juga mendidirikan sebuah program kursus Bahasa arab dan Bahasa inggris selain itu adapula pelatihan menjahit dan desain grafis dengan metode pembayaran menggunakan sampah. Program ini diikuti oleh berbagai kalangangan masyarakat dari mulai anak Sd samapi dengan dewasa. Seoerti kursus dimana kebanyakan pesertanya berasal dari anak sd dan smp. Biasanya kegiatan ini dilakukan dala seminggu sekali di tempat-tempat outdor maupun indoor. Sedangkan untuk kelas yang lainnya biasanya pesertanya dari anak-anak muda yang membuntuhkan keahlian khusus dibidang tertentu. Hal yang unik dari program ini adalah bagaimana metode pembayaran dari kursus ini menggunakan sampah. Dengan hal tersebut akademi ini menganggap bahwa dengan pembayaran menggunakan 
sampah ini bisa megurangi dan membangun kepedulian terhadap sampah dan lingkungan.

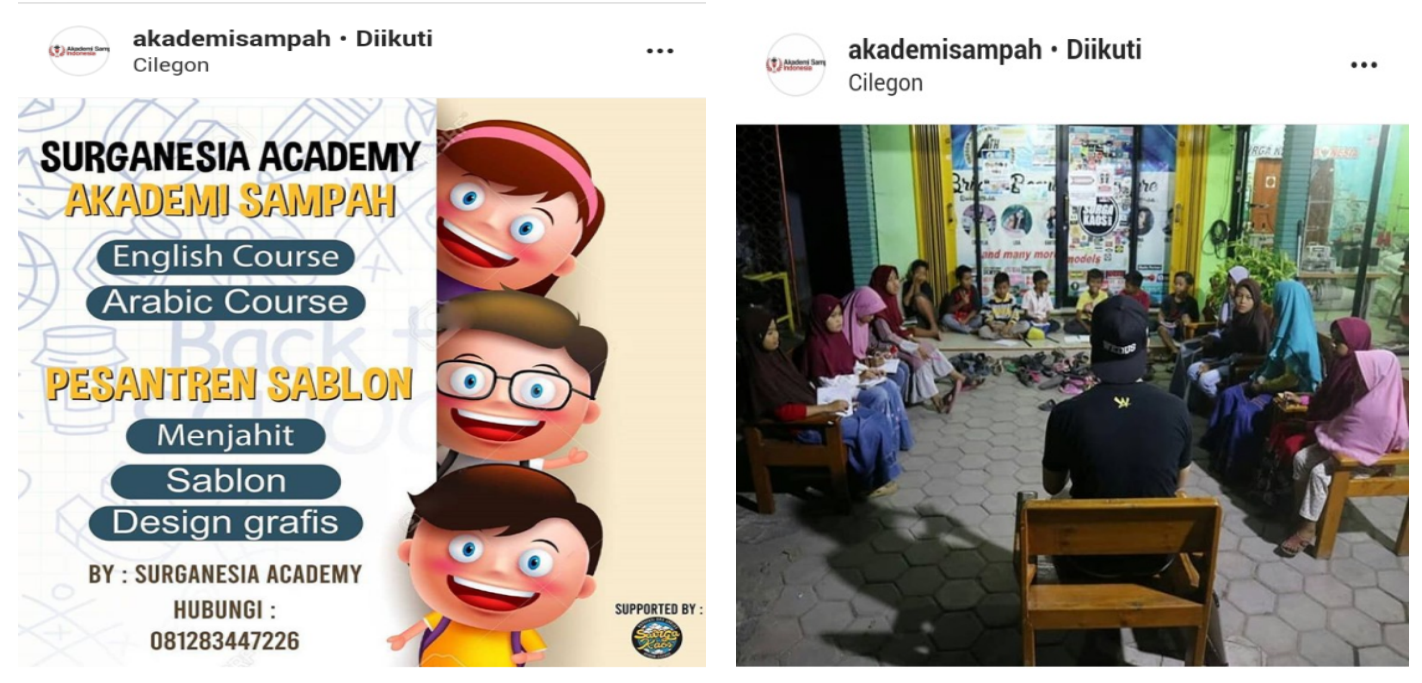

Sumber.ig@akademisampahindonesia

Program ini awalnya dinisiasi oleh Firdaus yang juga sebagai founder akademi sampah Indonesia dan juga owner dari surgakaos kemudian firdaus mengajak para relawan atau masyarakat untuk bergabung dan bersama-sama mengatasi masalah pencemaran lingkungan yang ada cilegon akibat kurangnya kesadaran masyarakat terhadap lingkungan dan diperparah dengan adanya limbah pabrik yang mencemari lingkungan pula.

\section{Aksi Menanam Pohon di SDN 1 Ciwedus}

Schusler \& Krasny (2010) mengemukakan bahwa Selain pendidikan lingkungan terdapat fokus gerakan lingkungan yang berupa perbaikan lingkungan fisik (physical environmental improvement). Kegiatannya berupa aksi restorasi suatu habitat alam tertentu, termasuk sungai, taman kota dan lingkungan fisik lainnya. Selain melakukan edukasi tentang lingkungan akademi sampah juga melakukan aksi menanam pohon bersama siswa-siswi dan guru-guru SDN 1 Ciwedus dimana sebelumnya mereka telah mendapatkan materi terkait bagaimana mengelola sampah dengan bijak dan melestarikan lingkungan kemudia mereka mempraktekan ilmu yang sudah di dapat tentang pendidikan lingkungan. Aksi lingkungan lansung yang dilakukan oleh akademi sampah Indonesia ini memberikan peran secara nyata untuk melindungi lingkungan dan melestarikan lingkungan seperti penghijauan lingkungan fisik SDN 1 Ciwedus.

Dalam aksi menanam pohon ini bukan hanya anak sd dan para anggota akademi sampah saja, melainnkan banyak golongan masyarakat juga berperan didalam nya. Penanaman pohon sebagai bentuk aksi langsung diharapkan juga memiliki dampak secara langsung kepada masyarakat. seminimal mungkin dapat menumbuhkan rasa kesadaran masyarakat betapa pentingnya menjaga lingkungan dengan melakukan menanam pohon. Dalam sudut lain menunjukan asih adanya sekelompok orang yang prihatin dan melakukan aksi nyata melihat keadan lingkungan yang rusak. 

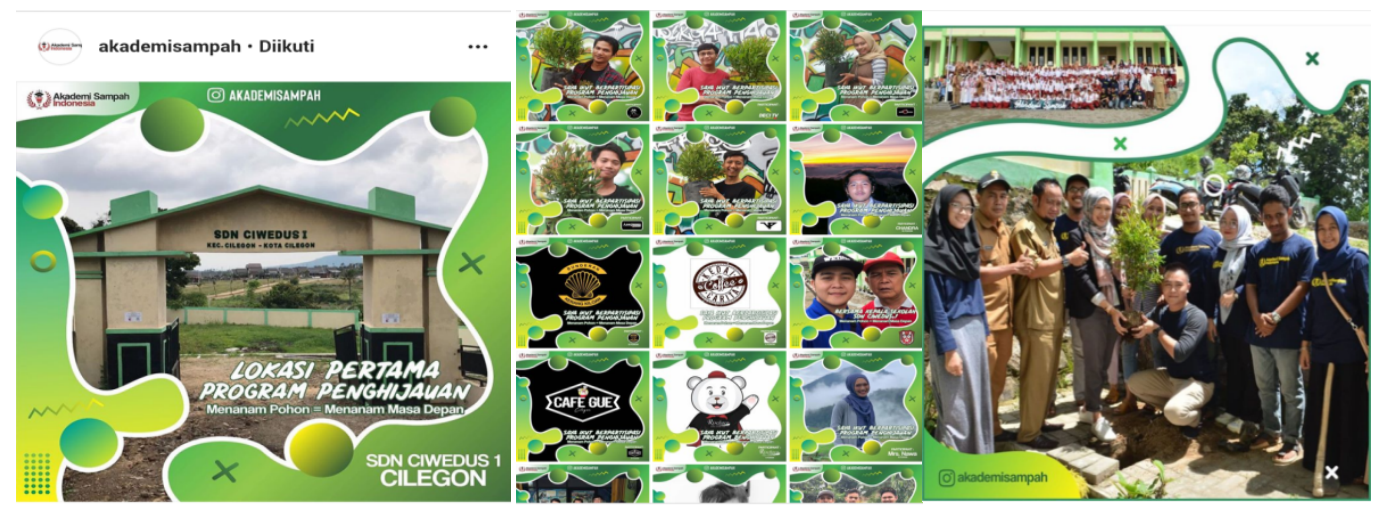

Sumber.ig@akademisampahindonesia

\section{Kesimpulan}

Usaha yang dilakuakn oleh komunitas akademi sampah dalam melakukan edukasi dan aksi ligkubngan di kota cilegon ini merupakan respon aktif terhadap keadaan lingkungan sekitar. Hal ini menunjukan bahwa saat ini masih adanya kepedulian dari segolongan masyarakat terhadapa permasalah lingkungan dan sampah. dengan begitu aksi ini menjadi jawaban bahwa yang beredar dimasyarakat mengenai sedikitnya manusia tidak peduli dan hanya bisa merusak lingkungan saja. Meskipun memang realitanya saat ini lebih banyak manusia yang tidak peduli lingkungan dibandingkan dengan yang peduli (Mardiana, 2019). Diuktikan dengan adanya aksi yang di pelopori oleh firdaus sehingga terbentukya komunitas akademi sampah pada bulan oktober 2019 ini menunjukan kegiatan yang dilakukan cukup tepat dalam kondisi saat ini.

Aksi yang dilakukan oleh akademi sampah ini memiliki keunikan tersendiri dalam setiap gerakannya. Mulai dari membangun kepedulian tehadap lingkungan ke masyarakat sampai dengan aksi langsung kelapangan untuk melakukan pembaharuan lingkungan. hal ini dilakukan dengan menggunkan cara-cara yang cukup menarik dan anti mainstream. Misalnya dengan melakukan penyluhan kepedulian sampah dai acara car free day, membuka kursus pemebelajaran bagi anak-anak sekolah dengan metode pembayaran dengan sampah dan kegiatan lainnya.

Mengacu pada pendapat Sonny (2010), bahwa ada beberapa pilihan untuk mencegah dan menghambat bencana lingkungan hidup, seperti perubahan paradigma dan kebijakan pembangunan, beralih ke industry bersih, penguatan dan pelurusan desentralisasi, perubahan cara pandang dan perilaku, dan aksi nyata. Aksi nyata ini lah yang dilakukan oleh komunitas akademi sampah. Aksi nyata merupakan kegiatan yang dilakukan secara individu maupun kelompok yang memiliki komitmen dalam menjag lingkungan. terdapat dua aksi nyata yang dilakukan oleh akademi sampah, edukasi lingkungan dan aksi perbaikan lingkungan fisik. 


\section{Tentang Penulis}

Dedi Rustandi merupakan mahasiswa prodi Ilmu Pemerintahan, Fakultas Ilmu Social Dan Politik Universitas Sultan Ageng Tirtayasa. Ketertarikannya dengan penelitian dalam tema Politik Lingkungan.

M Rian Bawazir merupakan mahasiswa prodi Ilmu Pemerintahan, Fakultas Ilmu Social Dan Politik Universitas Sultan Ageng Tirtayasa. Ketertarikannya dengan tema Politik Lingkungan.

\section{Ucapan Terimakasih}

Peneliti memberi ucapan terimakasih terhadap pihak-pihak yang telah berkontribusi dan memberikan dukungan dalam penelitian ini. pertama, kepada Allah SWT yang telah melancarkan peneliti dalam penelitian ini. Kepada dosen mata kuliah politik lingkungan bung Dian Hikmawan yang telah membimbing penulis secara masif dan berkelanjutan. Selain itu juga peneliti ucapkan terimaksih kepada narasumber dari pengurus komunitas Akademi Sampah yang telah bersedia menjadi narasumber dan memberiakn informasi yang mendukung penelitian. dan kepada pihak-pihak yang lainnya yang tidak bisa disebutkan satu persatu.

\section{Referensi}

Aditjondro dan George Junus.. Pola-pola Gerakan Lingkungan, Refleksi untuk Menyelamatkan Lingkungan dari Ekspansi Modal. Yogyakarta: Pustaka Pelajar. 2003.

Achsani risky a,dkk.. Penciptaan Tempat Dalam Pengelolaan Sampah Berbasis Komunitas Studi Kasus: Pengolahan Sampah oleh Komunitas My Darling dan Kakasih. Tidak publish. 2015.

Anih Sri Suryani. (2014). ( STUDI KASUS BANK SAMPAH MALANG ) ( A Case Study of MalangWaste Bank ) Anih Sri Suryani. Aspirasi, 5(1), 71-84.

Asteria, D., \& Heruman, H. (2016). BANK SAMPAH SEBAGAI ALTERNATIF STRATEGI PENGELOLAAN SAMPAH BERBASIS MASYARAKAT DI TASIKMALAYA, 23(1), 136-141.

Creswell. (2009). Research design: qualitative, quantitative and mixed approaches. Research Design. https:// doi.org/10.2307/1523157

Hikmawan, M. D., Ika Indriyany, A., \& Ma'asan Mayrudin, Y. (2019). Environmental Movement Against Mining Exploration in Bojonegara Serang Banten.

Jenkins.. Resource Mobilization Theory and the Study of Social Movements.

Keraf, A. Sonny. 2010. Krisis dan Bencana Lingkungan Hidup Global. Yogyakarta: Kanisius. 1983.

Mardiana, S. Y. (2019). Wilayah Gerak Earth Hour Menjadi Sarana Pemerintah dan Swasta Meraih Dukungan Publik. International Journal of Demos, 1(3), 394-406. 
Mulyaningsih , Ferani dkk.. Pendampingan Pengelolaan Sampah Berbasis Komunitas Posyandu Kartinikelurahan Ngaliyan - Kota Semarang. Forum Ilmu Sosial, Vol.42 No. 2, tahun 2015

Nugroho, Adityo.. Geliat Organisasi Pemuda Lingkungan (OPL) dalam Ranah Gerakan Lingkungandi Yogyakarta. Jurnal Ilmiah Sosiologi Agama. Volume 9, No. 1, tahun 2015

Nugroho, Adityo.. Komunitas Muda Urban Mengelola Sampah: Kajian Partisipatoris Gerakan Peduli Sampah Nasional di Kota Yogyakarta. Jurnal Pemikiran Sosiologi Volum e 4 No. 1, tahun 2017

Rahmadi didin s, dkk.. Penanganan Sampah Berbasis Desa Melalui Peran Pemuda. Jurnal Ilmu Sosial dan Pendidikan. Vol. 3. No. 3, tahun 2019

Suharko.. Pencegahan Bencana Lingkungan Hidup Melalui Pendidikan Lingkungan. Jurnal Manusia dan Lingkungan Volume 21, Nomor 2, tahun 2014 